\title{
Review Article \\ From Pathogenesis, Clinical Manifestation, and Diagnosis to Treatment: An Overview on Autoimmune Pancreatitis
}

\author{
Ou Cai and Shiyun Tan \\ Department of Gastroenterology, Renmin Hospital of Wuhan University, Wuhan, Hubei, China \\ Correspondence should be addressed to Shiyun Tan; tanshiyun@medmail.com.cn
}

Received 12 July 2016; Revised 1 November 2016; Accepted 27 December 2016; Published 19 January 2017

Academic Editor: Shahram Golbabapour

Copyright (C) 2017 Ou Cai and Shiyun Tan. This is an open access article distributed under the Creative Commons Attribution License, which permits unrestricted use, distribution, and reproduction in any medium, provided the original work is properly cited.

\begin{abstract}
Autoimmune pancreatitis (AIP) is a special type of chronic pancreatitis which is autoimmune mediated. The international consensus diagnostic criteria (ICDC) 2011 proposed two types of AIP: type I is associated with histological pattern of lymphoplasmacytic sclerosing pancreatitis (LPSP), characterized by serum IgG4 elevation, whereas type 2 is named idiopathic ductcentric pancreatitis (IDCP), with granulocytic epithelial lesion (GEL) and immunoglobulin G4 (IgG4) negative. The pathogenic mechanism is unclear now; based on genetic factors, disease specific or related antigens, innate and adaptive immunity may be involved. The most common clinical manifestations of AIP are obstructive jaundice and upper abdominal pain. The diagnosis can be made by a combination of parenchymal and ductal imaging, serum IgG4 concentrations, pancreatic histology, extrapancreatic disease, and glucocorticoid responsiveness according to ICDC 2011. Because of the clinical and imaging similarities with pancreatic cancer, general work-up should be done carefully to exclude pancreatic malignant tumor before empirical trial of glucocorticoid treatment. Glucocorticoid is the most common drug for AIP to induce remission, while there still exists controversy on steroid maintenance and treatment for relapse. Further studies should be done to identify more specific serum biomarkers for AIP, the pathogenic mechanisms, and the treatment for relapse.
\end{abstract}

\section{Introduction}

Autoimmune pancreatitis (AIP) is a special form of chronic pancreatitis that is autoimmune mediated [1]. Autoimmunity is defined as acquired immune reactivity against selfantigens. Autoimmune diseases (AIDs) occur when autoimmune responses lead to tissue damage. AIDs are often classified into two patterns; some are organ specific, for example, diabetes mellitus, in which the pancreas is the target organ, whereas others are systemic, for example, systemic lupus erythematosus (SLE), in which many tissues and organs of the body are damaged. Some common AIDs include diabetes mellitus type 1, Grave's disease, multiple sclerosis, psoriasis, rheumatoid arthritis, and SLE. AIP belongs to and shares some characteristics with AID in pathophysiology, clinical manifestations, and treatment and of course has its uniqueness. The prevalence rate of AIP in Japan was 4.6 per 100,000 individuals in 2011 and the annual incidence rate was 1.4 per 100,000 individuals [2]. In 1961, Sarles et al. [3] first reported a case about nonalcoholic chronic pancreatitis accompanied by hypergammaglobulinemia and predicted its association with an autoimmune process. In 1995, Yoshida et al. [4] first proposed the clinical entity of autoimmune pancreatitis. From then on, more and more scholars have paid attention to this rare type of chronic pancreatitis and substantial progress has been made in the recognition of AIP. The international consensus diagnostic criteria (ICDC) 2011 [5] proposed two forms of AIP: type I is associated with histological pattern of lymphoplasmacytic sclerosing pancreatitis (LPSP), accompanied with the serum immunoglobulin G4 (IgG4) elevation, whereas type 2 is characterized by idiopathic duct-centric pancreatitis (IDCP), with granulocytic epithelial lesion (GEL) and IgG4 negative $[5,6]$. The diagnosis of AIP depends on serum IgG4 concentration, pancreatic histology, pancreatic parenchymal and duct imaging, other organ involvement, and steroid reaction and is most often confused with pancreatic cancer, especially the focal AIP exhibiting mass formation $[5,7,8]$. Therefore, some patients 
with focal AIP have undergone surgical resection due to the suspicion of malignancy, despite recent improvements in radiological imaging modalities [9-13]. Kobayashi et al. [8] reported 11 (72.2\%) AIP patients had undergone surgery due to a preoperative diagnosis of mass formation pancreatitis with possible cancer revealed to be focal AIP. Hence, we sought to prepare an updated review about AIP to get a comprehensive knowledge about it.

\section{Classification}

The international consensus diagnostic criteria (ICDC) 2011 [5] had classified AIP into two types. Type 1 called lymphoplasmacytic sclerosing pancreatitis (LPSP), or without granulocyte epithelial lesions (GELs), has some characteristic features in histopathology: dense infiltration of plasma cells and lymphocytes; peculiar storiform fibrosis; obliterative phlebitis [15]; elevated IgG4-positive plasma cells (generally $>50$ cells per high-power field [HPF] [16]). It generally is believed to be the pancreatic manifestation of an IgG4 related systematic disease and is often accompanied with some extrapancreatic lesions, such as sclerosing cholangitis, sclerosing sialadenitis, and retroperitoneal fibrosis $[5,15,17]$. This type of AIP usually presents with obstructive jaundice in elderly male subjects and responds well to steroid therapy $[2,5,18]$.

Type 2 called idiopathic duct-centric pancreatitis (IDCP) has the unique characteristic feature of intraluminal and intraepithelial neutrophils in medium-sized and small ducts as well as in acini in histopathology, which is not seen in LPSP [5]. Also, they share some features in histopathology, such as periductal lymphoplasmacytic infiltration and storiform fibrosis. IDCP often has no or few IgG4-positive cells $(<10$ cells/HPF) and it seems to be a pancreatic-specific disorder, because it is IgG4 negative and is not associated with other organ involvement (OOI) [5]. Patients in IDCP are often a decade younger and do no show gender preference. IDCP lacks a serological marker and for its diagnosis pancreatic histology is a must [5]. The comparisons between the two types of AIP are in Table 1.

\section{Pathogenesis}

Recent studies have suggested several possible pathogenic factors in the development of AIP, though its pathogenic mechanism remains unclear. Based on genetic factors, disease specific or related antigens, innate and adaptive immunity may be involved [19].

3.1. Genetic Factors. Kawa et al. [20] first revealed that the susceptibility of AIP in Japanese patients may be associated with class II antigen haplotype of the major histocompatibility complex (HLA-DRB1* 0405-DQB1*0401). Later, Umemura et al. found that serum IgG4 concentrations in Japanese patients with AIP were significantly positively correlated with the number of susceptible Fc receptor-like 3 (FCRL3) genes alleles [21] expressed on B cells in 2006 and cytotoxic T lymphocyte antigen 4 (CTLA-4) [22] expressed
TABLE 1: Comparisons of the two types of AIP.

\begin{tabular}{|c|c|c|}
\hline Characteristics & Type 1 & Type 2 \\
\hline \multirow{3}{*}{$\begin{array}{l}\text { Other } \\
\text { nomenclatures } \\
{[5]}\end{array}$} & LPSP & IDCP \\
\hline & AIP without GEL & AIP with GEL \\
\hline & IgG4 related & IgG4 unrelated \\
\hline Ethnic [5] & $\begin{array}{c}\text { Asia }>\text { United States, } \\
\text { Europe }\end{array}$ & $\begin{array}{c}\text { Europe }>\text { United } \\
\text { States }>\text { Asian }\end{array}$ \\
\hline Age $[2,5,18]$ & 60 years or older & A decade younger \\
\hline Sex [5] & Usually male & Equal \\
\hline \multirow{3}{*}{ Symptom [5] } & $\begin{array}{l}\text { Obstructive jaundice } \\
\text { often }\end{array}$ & $\begin{array}{c}\text { Obstructive jaundice } \\
\text { often }\end{array}$ \\
\hline & Abdominal pain rare & $\begin{array}{l}\text { Abdominal pain } \\
\text { common }\end{array}$ \\
\hline & $\begin{array}{c}\text { Pancreas swelling } \\
\text { common }\end{array}$ & $\begin{array}{c}\text { Pancreas swelling } \\
\text { common }\end{array}$ \\
\hline Serology $[2,5]$ & $\begin{array}{l}\text { High serum IgG4, } \\
\text { auto-Ab+ }\end{array}$ & $\begin{array}{c}\text { Normal serum IgG4, } \\
\text { auto-Ab- }\end{array}$ \\
\hline \multirow{2}{*}{$\begin{array}{l}\text { Histopathology } \\
\text { [5] }\end{array}$} & $\begin{array}{c}\text { Lymphocyte and } \\
\text { plasmacyte infiltration } \\
\text { and fibrosis }\end{array}$ & $\begin{array}{c}\text { Granulocyte epithelial } \\
\text { lesion often with } \\
\text { destruction and }\end{array}$ \\
\hline & $\begin{array}{c}\text { Infiltration of IgG4 } \\
\text { plasma cells }\end{array}$ & $\begin{array}{c}\text { obliteration of the } \\
\text { pancreatic duct }\end{array}$ \\
\hline \multirow[b]{2}{*}{$\begin{array}{l}\text { Extrapancreatic } \\
\text { lesion }[5,15,17]\end{array}$} & Sclerosing cholangitis & \\
\hline & $\begin{array}{l}\text { Sclerosing sialadenitis } \\
\text { Retroperitoneal fibrosis, } \\
\text { etc. }\end{array}$ & Unrelated with OOI \\
\hline $\begin{array}{l}\text { Ulcerative colitis } \\
{[2,5]}\end{array}$ & Rare & Often \\
\hline $\begin{array}{l}\text { Histology } \\
\text { needed for } \\
\text { diagnosis [5] }\end{array}$ & No & Yes \\
\hline $\begin{array}{l}\text { Respond to } \\
\text { steroid }[2,5]\end{array}$ & Responsive & Responsive \\
\hline Relapse rate [5] & High & Low \\
\hline
\end{tabular}

on $\mathrm{CD}^{+}$and $\mathrm{CD}^{+} \mathrm{T}$ cells in 2008. In 2011, Ota et al. evaluated the association of AIP with single nucleotide polymorphisms (SNPs) and provided the evidence of KCNA3 [23] association with AIP. Chang et al. revealed the association of cystic fibrosis transmembrane conductance regulator (CFTR) gene variants [24] with AIP. Although the functions of the CFTR variants and their roles in the pathogenesis of AIP were not elucidated that clear, CFTR variants may play roles as disease modifiers in AIP (seen in Table 2). Undeniably, FCRL3 is found to be associated with various autoimmune diseases, such as rheumatoid arthritis, autoimmune thyroid disease, and SLE in Japanese populations $[25,26]$.

3.2. Immunogenic Factors. AIP is an autoimmune-mediated disease and abnormal immune response may play an important role in its pathophysiology. More than one autoantibody is seen in AIP patients and some other antigens like lactoferrin (LF), carbonic anhydrase (CA) II $[27,28]$, pancreatic secretory trypsin inhibitor (PSTI) [29], amylase alpha 2A [30], and type IV collagen [31] may also be involved in the 
TABLE 2: Genetic factors in the pathogenesis of AIP.

\begin{tabular}{|c|c|c|c|c|}
\hline Gene related & Cells involved & Sites related & Possible function in AIP & Referencing \\
\hline $\begin{array}{l}\text { HLA-DRB1*0405- } \\
\text { DQB1 }^{*} 0401\end{array}$ & $\mathrm{~T}$ cells & $\begin{array}{l}\text { HLA-DRB1*0405- } \\
\text { DQB1*0401 } \\
\text { haplotype }\end{array}$ & $\begin{array}{l}\text { Inducing an autoimmune } \\
\text { response; } \\
\text { genetic marker for non-HLA } \\
\text { gene associated disease } \\
\text { susceptibility }\end{array}$ & Kawa et al. [20] \\
\hline FCRL3 & B cells & FCRL3-110 alleles & Susceptibility with AIP & Umemura et al. [21] \\
\hline CTLA4 & $\mathrm{T}$ cells & $\begin{array}{c}+6230 \mathrm{G} / \mathrm{G} \\
+49 \mathrm{~A} / \mathrm{A}\end{array}$ & $\begin{array}{l}\text { Being related with AIP } \\
\text { resistance; } \\
\text { marker of risk of relapse in AIP }\end{array}$ & Umemura et al. [22] \\
\hline KCNA3 & T cells & $\begin{array}{c}\text { SNP (rs2840381, rs1058184, } \\
\text { rs2640480, rs1319782) }\end{array}$ & T cell proliferation and activation & Ota et al. [23] \\
\hline CFTR & - & $\begin{array}{c}\text { Variants (1556V, 5T, S42F, } \\
\text { etc.) }\end{array}$ & $\begin{array}{c}\text { Predictors of a slow and reduced } \\
\text { response to steroid treatment in } \\
\text { AIP }\end{array}$ & Chang et al. [24] \\
\hline
\end{tabular}

TABLE 3: Symptoms of AIP in different studies.

\begin{tabular}{lccccccc}
\hline Year & Number of patients & Ethnic & Male : female & Jaundice & Abdominal pain & Weight loss & No symptoms \\
\hline $2008[41]$ & 25 & Chinese & $22: 3$ & $18(72 \%)$ & $11(44 \%)$ & $10(40 \%)$ & $3(12 \%)$ \\
$2011[42]$ & 731 & 8 countries & - & Type 1 AIP 75\% & Type 1 AIP 41\% & - \\
$2015[43]$ & 705 & Chinese & $4.47: 1$ & Type 2 AIP 47\% & Type 2 AIP 68\% & - \\
$2016[44]$ & 52 & Spain & - & $27(51.9 \%)$ & $34(65.4 \%)$ & - & $-1 \%$ \\
\hline
\end{tabular}

pathogenesis of AIP. While combining amylase alpha 2A with IgG4 in diagnosing AIP, the specificity can be 99\%, higher than the specificity of $96 \%$ while using IgG4 only in a clinical study [32].

As for innate immune response, Watanabe et al. reported that activation of toll-like receptors (TLRs) and nucleotidebinding oligomerization domain- (NOD-) like receptors (NLRs) in monocytes and basophils of patients with IgG4 related disease (IgG4-RD) induced IgG4 production by $\mathrm{B}$ cells via $B$ cell activating factor (BAFF) $[33,34]$. What is more, Fukui et al. reported that abundant infiltration of TLR7 positive M2 macrophages was observed in the pancreatic tissues in type 1 AIP patients [35].

As for adaptive immune response, $\mathrm{B}$ cells and $\mathrm{T}$ cells are unavoidable topics. A recent study showed that increased $\mathrm{CD} 19^{+} \mathrm{CD} 24^{\text {high }} \mathrm{CD} 38^{\text {high }}$ regulatory $\mathrm{B}$ cells (Bregs) might suppress the disease activity of type 1 AIP, while the decreased $\mathrm{CD} 19^{+} \mathrm{CD} 24^{\text {high }} \mathrm{CD} 27^{+}$Bregs may be involved in the development of type 1 AIP [36]. Circulatory naïve regulatory $\mathrm{T}$ cells (Tregs) are significantly decreased in peripheral blood, while memory $\mathrm{T}$ cells are significantly increased in type 1 AIP patients [37]. In addition, prominent infiltration of Tregs with upregulation of IL-10 is observed in the liver of type 1 AIP patients [38]. Li et al. found significant $\mathrm{CD}^{+}{ }^{+} \mathrm{T}$ lymphocyte infiltration in the pancreas and extrapancreatic lesions in a case of AIP misdiagnosed as pancreatic cancer, indicating that $\mathrm{CD}^{+} \mathrm{T}$ lymphocyte might have some effect on the cause of AIP [39].

\section{Clinical Manifestation}

The clinical manifestations of AIP are complex and lack of specificity; therefore, it is extremely difficult to diagnose AIP from symptoms only. Type 1 AIP is typically diagnosed later in life (the mean age at diagnosis is older than 60 years) $[2,18]$. Obstructive painless jaundice and upper abdominal pain are the most common complaints. Other rare symptoms include body weight loss, general fatigue, and even no symptoms [40]. A series of studies have been focused on the symptoms and treatments of AIP in different countries and have got different results [41-44] (shown in Table 3). A retrospective study from China showed that the jaundice accounted for $72 \%$ and abdominal pain was 44\% [41]. Another multicenter study in Spain indicated that abdominal pain accounted for $65.7 \%$ and obstructive jaundice was $51.9 \%$ in AIP patients [44]. Ueki et al. [45] reveal that type 2 AIP can have the symptoms of acute, constant abdominal pain like in acute pancreatitis, different from the character of chronic pancreatitis.

Besides, AIP can cause extrapancreatic lesions including sclerosing cholangitis, retroperitoneal fibrosis, lachrymal and salivary gland lesions, pulmonary lesions including hilar lymphadenopathy, and tubulointerstitial nephritis, hypophysitis, chronic thyroiditis, and prostatitis $[5,15,17,40,46-50]$ and biliary tract is the most commonly involved extrapancreatic site $[43,46]$, which probably explains why there is painless jaundice in AIP patients.

AIP has certain comorbidities. Finkelberg et al. [51] reported that, in AIP patients, approximately 50\% have 
TABLE 4: Comparisons of diagnostic criteria in different countries.

\begin{tabular}{|c|c|c|c|c|}
\hline $\begin{array}{l}\text { Diagnostic } \\
\text { criteria }\end{array}$ & $\begin{array}{c}\text { Japanese } \\
\text { criteria(2006) [55] }\end{array}$ & SIHORts (2006) [57] & $\begin{array}{l}\text { Korean criteria } \\
(2007)[56]\end{array}$ & Asian criteria (2008) [58] \\
\hline A: imaging & $\begin{array}{l}\text { Diffuse or segmental } \\
\text { narrowing of the } \\
\text { MPD; diffuse or } \\
\text { localized } \\
\text { enlargement of the } \\
\text { pancreas }\end{array}$ & $\begin{array}{c}\text { Typical imaging } \\
\text { features: diffusely } \\
\text { enlarged gland with } \\
\text { delayed (rim) } \\
\text { enhancement; } \\
\text { diffusely irregular and } \\
\text { attenuated MPD } \\
\text { Atypical imaging } \\
\text { features: focal } \\
\text { pancreatic mass, focal } \\
\text { pancreatic duct } \\
\text { stricture }\end{array}$ & $\begin{array}{l}\text { Diffuse enlargement } \\
\text { of pancreas and } \\
\text { diffuse or segmental } \\
\text { irregular narrowing } \\
\quad \text { of MPD }\end{array}$ & $\begin{array}{l}\text { Typical imaging features: diffusely enlarged gland with } \\
\text { delayed (rim) enhancement; diffusely irregular and } \\
\text { attenuated MPD } \\
\text { Atypical imaging features: focal pancreatic mass, focal } \\
\text { pancreatic duct stricture }\end{array}$ \\
\hline B: serology & $\begin{array}{l}\text { High serum } \gamma \\
\text { globulin, IgG, IgG4, } \\
\text { or the presence of } \\
\text { autoantibodies }\end{array}$ & $\begin{array}{l}\text { Elevated serum IgG4 } \\
\text { level }\end{array}$ & $\begin{array}{c}\text { Elevated levels of } \\
\text { IgG and/or IgG4 or } \\
\text { detected } \\
\text { autoantibodies }\end{array}$ & $\begin{array}{l}\text { High level of serum IgG or IgG4 or detected } \\
\text { autoantibodies }\end{array}$ \\
\hline C: histology & $\begin{array}{l}\text { Infiltration of } \\
\text { lymphocytes and } \\
\text { plasma cells }\end{array}$ & $\begin{array}{l}\text { Lymphoplasmacytic } \\
\text { infiltrate with } \\
\text { storiform fibrosis } \\
\text { showing abundant } \\
\text { (>10 cells/HPF) } \\
\text { IgG4-positive cells }\end{array}$ & $\begin{array}{l}\text { Fibrosis and } \\
\text { lymphoplasmacytic } \\
\text { infiltration }\end{array}$ & $\begin{array}{c}\text { Lymphoplasmacytic infiltration with fibrosis, with } \\
\text { abundant } \\
\text { IgG4-positive cell infiltration }\end{array}$ \\
\hline $\begin{array}{l}\text { D: other organ } \\
\text { involvement }\end{array}$ & Not included & $\begin{array}{l}\text { Biliary stricture, } \\
\text { parotid/lacrimal } \\
\text { gland involvement, } \\
\text { mediastinal } \\
\text { lymphadenopathy, } \\
\text { retroperitoneal } \\
\text { fibrosis }\end{array}$ & Included & Not included \\
\hline E: steroid effect & Not included & Included & Included & Included \\
\hline $\begin{array}{l}\text { Definite } \\
\text { diagnosis }\end{array}$ & $\begin{array}{l}\text { Criterion } \mathrm{A}+\mathrm{B} \\
\text { Criterion } \mathrm{A}+\mathrm{C}\end{array}$ & $\begin{array}{l}\text { Criterion } A+B \\
\text { Criterion A + C } \\
\text { Criterion A + D } \\
\text { Criterion A + E }\end{array}$ & $\begin{array}{l}\text { Criterion } A+B \\
\text { Criterion } A+C \\
\text { Criterion } A+D \\
\text { Criterion A + E }\end{array}$ & $\begin{array}{c}\text { Criterion A + B } \\
\text { Criterion A + C } \\
\text { Histology shows the presence of lymphoplasmacytic } \\
\text { sclerosing pancreatitis in the resected pancreas }\end{array}$ \\
\hline
\end{tabular}

diabetes. More and more attention is focused on the relationship between AIP and inflammatory bowel disease, and the prevalence of IBD in patients with AIP seems to be increased compared to the general population, with 6 to $27 \%$ of AIP patients having concomitant IBD $[45,52,53]$, especially in type 2 AIP.

\section{Diagnosis}

5.1. Diagnosis Criteria for AIP. In 2002, the Japan Pancreas Society (JPS) [54] first proposed the diagnostic criteria for AIP and made the image abnormal findings such as irregular narrowing of the main pancreatic duct (MPD) (>one-third of the entire pancreas) and parenchymal swelling as necessity, accompanied with either of the following two: (1) serology showing hypergammaglobulinemia $(>2 \mathrm{~g} / \mathrm{dL}$, autoantibodies) and serum IgG elevation (>1800 mg/dL) and (2) characteristic pathological findings including lymphoplasmacytic infiltration with fibrosis. The JPS criterion was revised in 2006 [55], and it first proposed the IgG4 elevation as the serology finding, which is important for the diagnosis of AIP even until now. Because of the limitations in JPS, 2006 [55], Korean Kim criteria [56] occurred, including four parts of imaging, laboratory examinations, histology, and steroid effect. Subsequently, HISORt [14, 57] (based on the four parts in Korean criteria, other organ involvement was added), Asian [58] (histology only can be used to diagnose AIP when it meets the demand), and Manheim criteria [59] have been proposed around the world. In 2011, Shimosegawa et al. [5] first proposed the ICDC for AIP, which is the most accepted major diagnostic criterion. Later, JPS $2011[60,61]$ was proposed in response to the ICDC's inclusion of response to steroid treatment. Table 4 shows the comparisons of diagnostic criteria in different countries.

There are several diagnostic criteria for AIP in different countries, but ICDC is the first universally accepted criterion of AIP because it considers ethnic and region differences and classifies AIP into two subtypes. The diagnosis of AIP includes five dimensions: serology, histology, imaging, other organ involvement, and steroid effect. 
5.2. Serology Changes in AIP. Since being proposed by JPS 2006, serum IgG4 elevation is widely used in the diagnosis of AIP. However, IgG4 has its limitations. Studies have shown that $4-10 \%$ of both healthy controls and controls with other diseases have high serum IgG4 concentrations [62-64]. In addition, about $20 \%$ of patients with AIP have normal serum IgG4 concentrations at presentation $[63,65]$. A systematic review with meta-analysis about $\operatorname{IgG}$ and $\operatorname{IgG} 4$ shows that the pooled sensitivity of serum IgG4 was 0.74 and the pooled specificity was 0.94 [66]. An ideal serological marker should be both sensitive and specific, while IgG4 is neither sufficiently sensitive nor specific. Besides, elevated IgG4 is seen only in type 1 AIP whereas type 2 AIP often has normal IgG4 level. Considering these two factors, searching for new serological marker is essential and valuable. Song et al. [67] proposed combining measurement of serum IgG and IgG4 instead of IgG4 alone to increase the sensitivity in diagnosing AIP. Recently, Hao et al. [68] explored that hybrid kappa $(\kappa) /$ lambda $(\lambda)$ antibody, which composes a substantial portion of IgG4 in normal human serum and is formed by two IgG4 heavy chains plus one $\kappa$ and one $\lambda$ light chain, is a new serological marker for diagnosing AIP. The sensitivity and specificity of hybrid $\kappa / \lambda$ antibody were $80.3 \%$ and $91 \%$, respectively. While combining serum IgG4 and the hybrid $\kappa / \lambda$ antibody, the diagnostic sensitivity could be increased from $78.7 \%$ to $90.2 \%$ compared with serum IgG4 alone without sacrificing specificity significantly.

\subsection{Imaging Features of AIP in Different Examinations. Ultra-} sound (US) is widely used for its noninvasiveness, low price, and easy operation. US can present the diffuse enlargement and hypoechoic pancreas, but it cannot show the irregular narrowing or stenosis of the pancreatic duct. Quantitative perfusion analysis in pancreatic contrast enhanced ultrasound (DCE-US) can show the vascular lesions of pancreas and play a significant role in differentiating AIP from pancreatic cancer [69].

Computed tomography (CT) is the most important tool to diagnose AIP and distinguish it from pancreatic cancer. The typical image finding is diffuse morphological pancreatic parenchymal enlargement and the atypical findings include focal enlargement of the pancreas, no enlargement or normal pancreas, and mixed patterns [57, 70-73]. AIP demonstrates a diminished pattern of enhancement in the arterial phase and a relatively increased or prolonged enhancement in the delayed or venous phase [72, 74]. And a capsule-like low density rim is a distinctive finding on CT in AIP [72]. However, if there is low density mass on contrast enhanced $\mathrm{CT}$, pancreatic cancer should be considered.

Magnetic resonance imaging (MRI) has advantages over CT on the capsule-like imaging of the pancreatic duct and surrounding lesions, which is the result of the fibrosis of the pancreas. The typical MRI findings include hypointense signal on $\mathrm{T} 1$ weighted images and relatively $\mathrm{T} 2$ hyperintense signal [75]. Diffusion weighted imaging (DWI) has been increasingly utilized as a MRI sequence for evaluating pancreas [76-78]. Kim et al. [79] found that while perfusion fraction $(f)$ is 0.933 , it is most useful for differentiating
AIP and normal pancreas and its sensitivity is $85.7 \%$ and specificity is $100 \%$. And perfusion fraction $(f)$ and perfusionrelated diffusion coefficient $\left(D_{\text {fast }}\right)$ are more useful than pure molecule diffusion coefficient $\left(D_{\text {slow }}\right)$ in differentiating pancreatic diseases from normal pancreas.

Magnetic Resonance Cholangiopancreatography (MRCP) is widely used for its advantage of high quality image and noninvasiveness, but for its less sensitivity in the focal form of AIP and pancreatic cancer, it cannot replace ERCP completely. MRCP could show the diffused narrow or segmental stenosis of main pancreatic ducts, the pancreatic segment of common bile duct stricture, proximal bile duct dilation, and gallbladder enlargement [80].Endoscopic retrograde cholangiopancreatography (ERCP) is an invasive method but it is feasible in treatment and diagnosis of AIP and the incidence of ERCP-related adverse events is low in patients with type 1 AIP [81]. Ductal imaging, ERCP, may show a long, narrow ductal stricture, or multiple, noncontinuous strictures without marked upstream dilation, and side branches arising from the stricture $[82,83]$. The multicenter study carried out by Sugumar et al. [84] has highlighted that the ability of ERCP to diagnose AIP based on ERCP feature alone is limited, but taken together with clinical symptoms, serology, and/or histology it can be useful.

Endoscopic Ultrasound (EUS) can be utilized to evaluate the pancreatic parenchyma, bile duct, and pancreatic duct, as well as in evaluating the bile duct stricture. The EUS guided fine needle aspiration (EUS-FNA) is not included in ICDC as a method for histopathologic diagnosis of AIP because of the difficulty in obtaining adequate specimens for histological analysis. Although EUS-FNA has its limitations for $20.5 \%$ unsuccessful adequate tissue sampling, 23 of the 53 undetermined patients could be diagnosed as definitive type 1 AIP without the aid of pancreatic imaging, serology, other organ involvement, and response to steroids [84], which is unique. The nationwide epidemiology survey of AIP in Japan in 2011 found that the use of EUS-FNA increased to $63.8 \%$ from $48.4 \%$ and the utility of EUS-FNA for establishing of AIP will be further validated in the future [2, 85-87].

Positron Emission Computed Tomography (PET) can get the total image of every part of the body and it is especially sensitive in finding tumors. PET is more sensitive than conventional imaging to detect organ involvement and uptake of fluorodeoxyglucose in organs other than the pancreas often suggests AIP when the clinical characteristic, histology, and serum detection incline the diagnosis of IgG4 related disease $[88,89]$.

Every imaging method has its cons and pros (shown in Table 5). What should be emphasized is that methods are not isolated; we can combine two or more methods when needed. Uchida et al. [90] stated that in their institution they initially use CT scans to evaluate the enlarged pancreas followed by evaluation of the main pancreatic duct by ERP. For pancreatic head lesions with obstructive jaundice or biliary enzyme abnormality due to biliary stricture, they first perform diagnostic and therapeutic ERCP. For pancreatic head lesions without obstructive jaundice, they perform 
TABLE 5: Cons and pros of different kinds of imaging.

\begin{tabular}{|c|c|c|c|c|}
\hline Imaging & Imaging findings & Advantage & Disadvantage & When to select \\
\hline US & $\begin{array}{l}\text { Diffuse enlargement, hypoechoic } \\
\text { pancreas }\end{array}$ & $\begin{array}{l}\text { Low price, noninvasive, and } \\
\text { easy to operate }\end{array}$ & Lack of specificity & Physical examination \\
\hline $\mathrm{CT}$ & $\begin{array}{l}\text { Diffuse morphological pancreatic } \\
\text { parenchymal enlargement, focal } \\
\text { enlargement of the pancreas [72] }\end{array}$ & $\begin{array}{l}\text { Being noninvasive, being } \\
\text { easy to operate, high } \\
\text { quality image for pancreatic } \\
\text { parenchymal enlargement, } \\
\text { differentiating AIP from } \\
\text { pancreatic cancer }\end{array}$ & $\begin{array}{l}\text { Less sensitivity in the } \\
\text { pancreatic and bile duct } \\
\text { lesion than MRCP and } \\
\text { MRI }\end{array}$ & $\begin{array}{l}\text { Evaluate the pancreatic } \\
\text { parenchyma and } \\
\text { differentiate AIP from } \\
\text { pancreatic cancer }\end{array}$ \\
\hline MRI & $\begin{array}{c}\text { Hypointense signal on } \mathrm{T} 1 \\
\text { weighted images and relatively } \\
\text { T2 hyperintense signal [75] }\end{array}$ & $\begin{array}{l}\text { Being noninvasive, being } \\
\text { easy to operate, showing } \\
\text { the pancreatic fibrosis }\end{array}$ & $\begin{array}{c}\text { Less sensitivity in } \\
\text { pancreatic parenchymal } \\
\text { than CT }\end{array}$ & $\begin{array}{c}\text { Evaluate the pancreatic } \\
\text { parenchyma }\end{array}$ \\
\hline MRCP & $\begin{array}{l}\text { Diffused narrow or segmental } \\
\text { stenosis of main pancreatic } \\
\text { ducts, the pancreatic segment of } \\
\text { common bile duct stricture, } \\
\text { proximal bile duct dilation, and } \\
\text { gallbladder enlargement [80] }\end{array}$ & $\begin{array}{l}\text { Being noninvasive, being } \\
\text { easy to operate, presenting } \\
\text { the pancreatic duct and bile } \\
\text { duct and their relationship }\end{array}$ & $\begin{array}{l}\text { Less sensitivity in the } \\
\text { focal lesion of pancreatic } \\
\text { parenchymal than CT }\end{array}$ & $\begin{array}{c}\text { Evaluate the bile duct, } \\
\text { pancreatic duct, and bile } \\
\text { duct stricture }\end{array}$ \\
\hline ERCP & $\begin{array}{c}\text { Diffuse, irregular narrowing of } \\
\text { the MPD }[82,83]\end{array}$ & $\begin{array}{l}\text { Diagnosis and treatment } \\
\text { simultaneously, especially } \\
\text { in the case of jaundice }\end{array}$ & Invasive & $\begin{array}{l}\text { Evaluating the bile duct, } \\
\text { pancreatic duct, and bile } \\
\text { duct stricture, treatment for } \\
\text { jaundice }\end{array}$ \\
\hline EUS-FNA & - & $\begin{array}{l}\text { Get the tissue with much } \\
\text { less wound than surgery }\end{array}$ & $\begin{array}{c}\text { Invasive May not get } \\
\text { adequate tissue }\end{array}$ & $\begin{array}{l}\text { Get the pancreatic tissue } \\
\text { sample }\end{array}$ \\
\hline PET & $\begin{array}{c}\text { Uptake of fluorodeoxyglucose in } \\
\text { organs other than the pancreas } \\
\qquad[88,89]\end{array}$ & $\begin{array}{l}\text { Other organ involvement is } \\
\text { easily detected }\end{array}$ & Expensive & $\begin{array}{c}\text { Assess the other organ } \\
\text { involvement, exclude } \\
\text { malignant tumor }\end{array}$ \\
\hline
\end{tabular}

EUS-FNA followed by diagnostic and therapeutic ERCP. For pancreatic body or tail lesions, they first perform EUS-FNA.

\section{Differential Diagnosis and the Strategy for Distinguishing AIP from Pancreatic Cancer}

As a new and relatively rare pancreatic lesion, AIP is easy to be neglected and misdiagnosed as pancreatic cancer for its clinical and imaging features. As is proposed in ICDC, IgG4 elevation is a high-specific serum marker for AIP $[49,50]$. However, Ngwa et al. [91] reported that $10.1 \%$ of 548 patients with pancreatic cancer have elevated serum IgG4, which may be confusing when serum IgG4 is used to differentiate pancreatic cancer and AIP. Serum CA19-9 was stated to be useful for distinguishing AIP from pancreatic cancer [92], while CA19-9 can also be elevated in other pancreatic diseases or in other pathological states [93]. Thus, so far, a simple serological marker for the differential diagnosis of AIP from pancreatic cancer is still lacking. What is worse, the differentiation by imaging also presents some problems, especially pancreatic cancer and the focal AIP exhibiting mass formation $[7,8]$. Thus, a thorough work-up is essential before either surgery or steroid treatment is planned.

Here we present the American diagnostic strategy to differentiate AIP from pancreatic cancer. In patients with obstructive jaundice and/or pancreatic mass CT findings typical for AIP, the presence of any collateral evidence for AIP (elevated IgG4 or autoantibodies or other organ involvement) is sufficient to make the diagnosis. On the other hand, those with any of the features highly suggestive of pancreatic cancer should generally be managed as cancer unless there is clear evidence of other organ involvement suggestive of AIP. Patients without typical findings of AIP, including those with indeterminate CT findings, should undergo work-up for cancer. If negative, additional collateral evidence for AIP (serum IgG4) should be sought. Diagnosis of AIP is confirmed by pancreatic core biopsy, steroid trial and surgical resection [14] (Figure 1).

\section{Treatment for AIP}

Glucocorticoids are the routine drug for AIP and rapid response to steroid treatment is one of the primary characteristics of AIP. A poor response to steroid therapy might suggest misdiagnosis, especially in the case of pancreatic cancer. Hart et al. [18] conducted a multicenter, international analysis (1064 patients), showing that 99\% of type 1 AIP and $92 \%$ of type 2 AIP got clinical remission after steroid treatment. Before induction of remission by an initial steroid therapy, management of blood glucose and biliary drainage is recommended in patients with diabetes mellitus and obstructive jaundice. Generally, patients are given initial oral prednisolone dose of $0.6 \mathrm{mg} / \mathrm{Kg} /$ day for induction of remission, which is administered for 2 to 4 weeks. The dose is then tapered by $5 \mathrm{mg}$ every 1 to 2 weeks to a maintenance dose (2.5-5 mg/day) that should be continued for three years as 


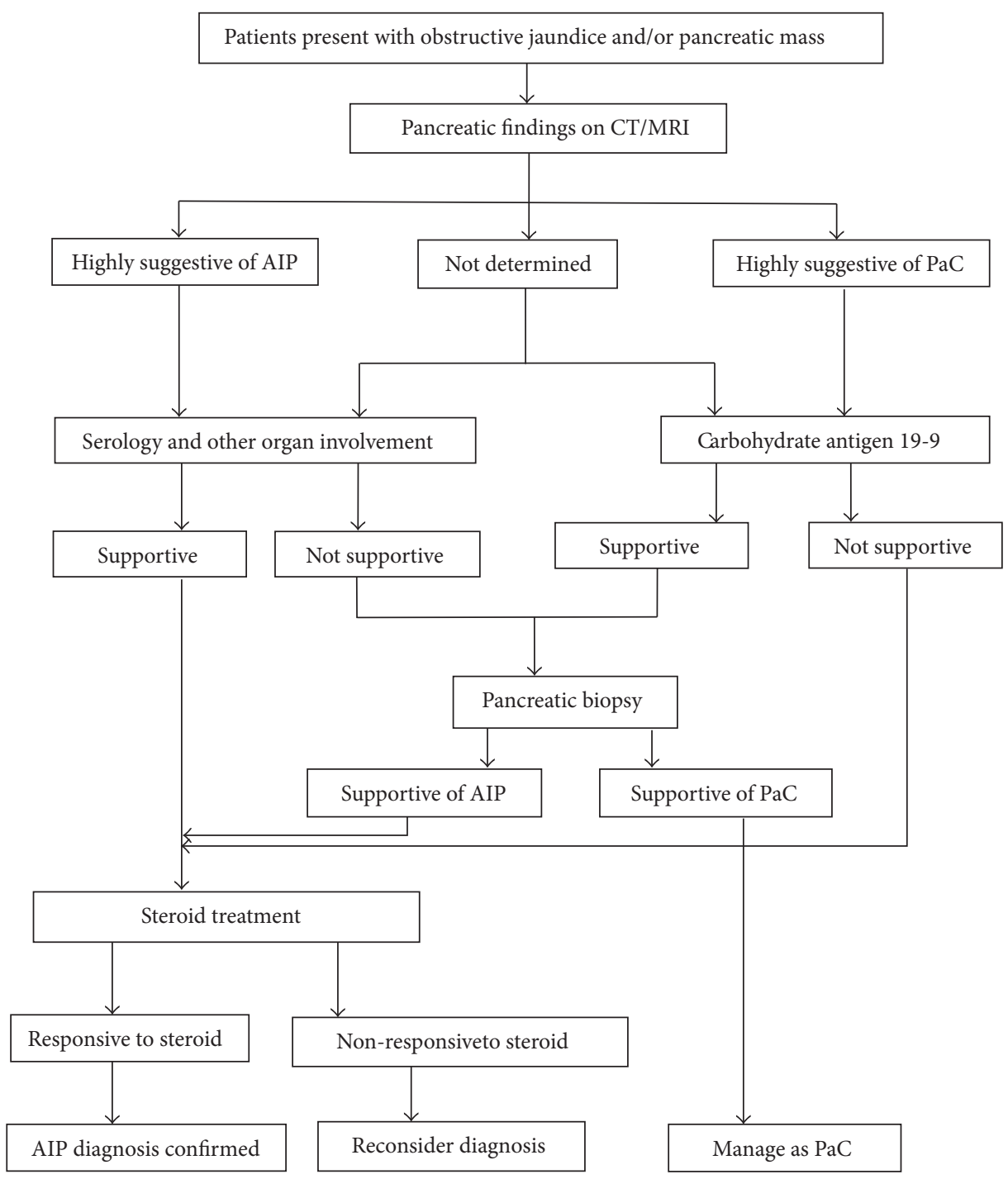

FIGURE 1: Strategy for distinguishing AIP from pancreatic cancer [14]. CT: computed tomography; MRI: magnetic resonance imaging; PaC: pancreatic cancer; OOI/O: other organ involvement; S: serology; CA19-9: carbohydrate antigen 19-9.

maintenance therapy in Japan [94] and the regimen is utilized in most Asian countries. In a multicenter study in Japan, Kamisawa et al. [95] reported that relapse occurred significantly less during maintenance steroid therapy than after the discontinuation of therapy (23\% versus 34\%, $P<0.05$ ), while in European and American countries, maintenance therapy is not commonly used. Ghazale et al. [96] conducted a study and the initial steroid regimen was as follows: prednisolone $40 \mathrm{mg} /$ day orally for 4 weeks, then tapering by $5 \mathrm{mg} /$ week until 11 weeks, and then having a maintenance dose from 12 weeks (Table 6). As a result, 16 (53\%) of 30 patients associated with sclerosing cholangitis relapsed during a median followup of 29.5 months. Moreover, long time maintenance steroid therapy may cause steroid-related side effects and not all patients can tolerate them. Therefore, whether a maintenance therapy is needed or not needs international discussion.

In a multicenter study in Japan, the cumulative rate of relapse after starting steroid therapy was $56 \%$ at 1 year, $76 \%$ at two years, and 92\% after 3 years [95]. Hart et al. [18] found the relapse was related to IgG4 related sclerosing cholangitis, no business with serum IgG4 level or pancreatic parenchyma involvement (diffuse or focal pancreatic parenchyma enlargement), while Shimizu et al. [97] confirmed that the rate of decrease in serum IgG4 level was significantly higher in nonrelapse group than in the relapse group after steroid treatment and it might be a predictor of a relapse of AIP. The treatment for relapse is restarting steroids. Whether or not to use alternative immunosuppressant, such as azathioprine, methotrexate, and mycophenolate mofetil $[5,18]$, depends on the patient's reaction to re-steroid therapy and his tolerance to steroid. Unfortunately, in some cases, the patients cannot tolerate both steroid and immunosuppressant and require drug discontinuation. Rituximab, a monoclonal CD20 antibody, has been shown to be useful in treating AIP patients $[98,99]$. The effectiveness of rituximab shed light on the role of B cells in the pathogenesis of AIP because of the B cell depletion. As 
TABLE 6: Management strategy of AIP based on immunology therapy.

\begin{tabular}{|c|c|c|c|}
\hline Time & $0-12$ weeks & 12 weeks -6 months & 6 months -3 years \\
\hline \multicolumn{4}{|c|}{$\begin{array}{l}\text { Japan and Asian } \\
\text { countries [94] }\end{array}$} \\
\hline Objective & Induction of remission & \multicolumn{2}{|c|}{ Maintenance therapy } \\
\hline Drug & Prednisolone & \multicolumn{2}{|c|}{ Prednisolone } \\
\hline Dose & $\begin{array}{c}0.6 \mathrm{mg} / \mathrm{Kg} / \text { day for } 2-4 \text { weeks, tapered by } 5 \mathrm{mg} \\
\text { every } 1-2 \text { weeks to a maintenance dose }\end{array}$ & \multicolumn{2}{|c|}{$2.5-5.0 \mathrm{mg} /$ day } \\
\hline \multicolumn{4}{|c|}{$\begin{array}{l}\text { American and } \\
\text { European countries } \\
{[19]}\end{array}$} \\
\hline Objective & Induction of remission & Maintenance therapy & Observation \\
\hline Drug & Prednisolone & Prednisolone & $\begin{array}{l}\text { Immunomodulator/rituximab (when } \\
\text { relapsing) }\end{array}$ \\
\hline Dose & $\begin{array}{c}30-40 \mathrm{mg} / \text { day for } 2-4 \text { weeks, tapered by } 5 \mathrm{mg} \\
\text { every } 1-2 \text { weeks to a maintenance dose }\end{array}$ & $5.0-7.5 \mathrm{mg} /$ day & Undetermined \\
\hline
\end{tabular}

rituximab is the only drug for induction of remission other than glucocorticoids, it would be extremely useful in patients who are unable to tolerate high-dose corticosteroids, require high doses of prednisolone to maintain remission, or have failed to respond to immunomodulator therapy. Currently approved for treating B cell lymphoma and rheumatoid arthritis, rituximab's approval for treating AIP will come true.

The prognosis of AIP is good in general and the long-term complication is rare. Pancreatic duct stones and canceration are the main sequelae [18]. Kanno et al. [2] conducted the nationwide epidemiological survey in Japan in 2011 and found that during the course of observation (1623.3 days), malignant tumors were detected in 109 of 923 patients (11.2\%). Shiokawa et al. [100] reported that AIP patients had a high risk of having various cancers, while Hart et al. [101] reported that cancer risk of AIP patients was similar to that of control subjects. Whether AIP is the risk factor for developing cancer needs further investigation.

\section{Conclusion}

In conclusion, AIP is a special type of chronic pancreatitis, whose pathogenic mechanism, maybe a combination of genetic factors and immunity abnormality, needs more work to be clarified. The diagnosis of AIP depends on serology, imaging, histology, other organ involvement, and reaction to steroids, while high sensitive serum biomarkers for AIP subtypes lack. AIP reacts well to steroids, but controversy exists on the steroid maintenance and treatment for relapse. For AIP shares similarity with pancreatic cancer in clinical and imaging characteristics, general work-up is necessary to differentiate them. Future research may be focused on the pathogenesis, the novel serum biomarker, and the relapse treatment for AIP.

\section{Competing Interests}

The authors declare that they have no competing interests.

\section{References}

[1] T. Kamisawa, T. Tabata, S. Hara et al., "Recent advances in autoimmune pancreatitis," Frontiers in Physiology, vol. 3, article no. 374, 2012.

[2] A. Kanno, A. Masamune, K. Okazaki et al., "Nationwide epidemiological survey of autoimmune pancreatitis in Japan in 2011," Pancreas, vol. 44, no. 4, pp. 535-539, 2015.

[3] H. Sarles, J.-C. Sarles, R. Muratore, and C. Guien, "Chronic inflammatory sclerosis of the pancreas-an autonomous pancreatic disease?" The American Journal of Digestive Diseases, vol. 6, no. 7, pp. 688-698, 1961.

[4] K. Yoshida, F. Toki, T. Takeuchi, S.-I. Watanabe, K. Shiratori, and N. Hayashi, "Chronic pancreatitis caused by an autoimmune abnormality-proposal of the concept of autoimmune pancreatitis," Digestive Diseases and Sciences, vol. 40, no. 7, pp. 1561$1568,1995$.

[5] T. Shimosegawa, S. T. Chari, L. Frulloni et al., "International consensus diagnostic criteria for autoimmune pancreatitis: guidelines of the international association of pancreatology," Pancreas, vol. 40, no. 3, pp. 352-358, 2011.

[6] S. Fritz, F. Bergmann, L. Grenacher et al., "Diagnosis and treatment of autoimmune pancreatitis types 1 and 2," British Journal of Surgery, vol. 101, no. 10, pp. 1257-1265, 2014.

[7] S. Hoshimoto, K. Aiura, M. Tanaka, M. Shito, T. Kakefuda, and H. Sugiura, "Mass-forming type 1 autoimmune pancreatitis mimicking pancreatic cancer," Journal of Digestive Diseases, vol. 17, no. 3, pp. 202-209, 2016.

[8] G. Kobayashi, N. Fujita, Y. Noda, K. Ito, and J. Horaguchi, "Autoimmune pancreatitis: with special reference to a localized variant," Journal of Medical Ultrasonics, vol. 35, no. 2, pp. 41-50, 2008.

[9] S. Ben Abid, R. Hefaiedh, S. Zghab, N. Miloudi, L. Gharbi, and M. T. Khalfallah, "Pseudotumoral autoimmune pancreatitis mimicking a pancreatic cancer: a very difficult disease to diagnose," Clinics and Practice, vol. 2, no. 4, 2012.

[10] K. Dede, F. Salamon, A. Taller, and A. Bursics, "Autoimmune pancreatitis mimicking pancreatic tumor," Magyar Sebészet, vol. 67, no. 1, pp. 18-23, 2014.

[11] R. S. C. Lo, R. K. Singh, A. S. Austin, and J. G. Freeman, "Autoimmune pancreatitis presenting as a pancreatic mass 
mimicking malignancy," Singapore Medical Journal, vol. 52, no. 4, pp. e79-e81, 2011.

[12] I. Matsumoto, M. Shinzeki, H. Toyama et al., "A focal massforming autoimmune pancreatitis mimicking pancreatic cancer with obstruction of the main pancreatic duct," Journal of Gastrointestinal Surgery, vol. 15, no. 12, pp. 2296-2298, 2011.

[13] G.-F. Sun, C.-J. Zuo, C.-W. Shao, J.-H. Wang, and J. Zhang, "Focal autoimmune pancreatitis: radiological characteristics help to distinguish from pancreatic cancer," World Journal of Gastroenterology, vol. 19, no. 23, pp. 3634-3641, 2013.

[14] S. T. Chari, N. Takahashi, M. J. Levy et al., "A diagnostic strategy to distinguish autoimmune pancreatitis from pancreatic cancer," Clinical Gastroenterology and Hepatology, vol. 7, no. 10, pp. 1097-1103, 2009.

[15] T. Kamisawa, Y. Zen, S. Pillai, and J. H. Stone, "IgG4-related disease," The Lancet, vol. 385, no. 9976, pp. 1460-1471, 2015.

[16] V. Deshpande, Y. Zen, J. K. Chan et al., "Consensus statement on the pathology of IgG4-related disease," Modern Pathology, vol. 25, no. 9, pp. 1181-1192, 2012.

[17] S. Kawa, K. Okazaki, T. Kamisawa et al., "Amendment of the Japanese consensus guidelines for autoimmune pancreatitis, 2013 II. Extrapancreatic lesions, differential diagnosis," Journal of Gastroenterology, vol. 49, pp. 765-784, 2014.

[18] P. A. Hart, T. Kamisawa, W. R. Brugge et al., "Long-term outcomes of autoimmune pancreatitis: a multicentre, international analysis," Gut, vol. 62, no. 12, pp. 1771-1776, 2013.

[19] K. Okazaki and K. Uchida, "Autoimmune pancreatitis: the past, present, and future," Pancreas, vol. 44, no. 7, pp. 1006-1016, 2015.

[20] S. Kawa, M. Ota, K. Yoshizawa et al., "HLA DRB1*0405$\mathrm{DQB1}^{\star} 0401$ haplotype is associated with autoimmune pancreatitis in the Japanese population," Gastroenterology, vol. 122, no. 5, pp. 1264-1269, 2002.

[21] T. Umemura, M. Ota, H. Hamano, Y. Katsuyama, K. Kiyosawa, and S. Kawa, "Genetic association of Fc receptor-like 3 polymorphisms with autoimmune pancreatitis in Japanese patients," Gut, vol. 55, no. 9, pp. 1367-1368, 2006.

[22] T. Umemura, M. Ota, H. Hamano et al., "Association of autoimmune pancreatitis with cytotoxic T-lymphocyte antigen 4 gene polymorphisms in Japanese patients," The American Journal of Gastroenterology, vol. 103, no. 3, pp. 588-594, 2008.

[23] M. Ota, T. Ito, T. Umemura et al., "Polymorphism in the KCNA3 gene is associated with susceptibility to autoimmune pancreatitis in the Japanese population," Disease Markers, vol. 31, no. 4, pp. 223-229, 2011.

[24] M.-C. Chang, I.-S. Jan, P.-C. Liang et al., "Cystic fibrosis transmembrane conductance regulator gene variants are associated with autoimmune pancreatitis and slow response to steroid treatment," Journal of Cystic Fibrosis, vol. 14, no. 5, article 1230, pp. 661-667, 2015.

[25] Y. Kochi, R. Yamada, A. Suzuki et al., "A functional variant in FCRL3, encoding Fc receptor-like 3, is associated with rheumatoid arthritis and several autoimmunities," Nature Genetics, vol. 37, pp. 478-485, 2005.

[26] K. Ikari, S. Momohara, T. Nakamura et al., "Supportive evidence for a genetic association of the FCRL3 promoter polymorphism with rheumatoid arthritis," Annals of the Rheumatic Diseases, vol. 65, no. 5, pp. 671-673, 2006.

[27] H. Nishi, A. Tojo, M. L. Onozato et al., "Anti-carbonic anhydrase II antibody in autoimmune pancreatitis and tubulointerstitial nephritis," Nephrology Dialysis Transplantation, vol. 22, no. 4, pp. 1273-1275, 2007.
[28] K. Okazaki, K. Uchida, M. Ohana et al., "Autoimmune-related pancreatitis is associated with autoantibodies and a Th1/Th2type cellular immune response," Gastroenterology, vol. 118, no. 3, pp. 573-581, 2000.

[29] M. Asada, A. Nishio, K. Uchida et al., "Identification of a novel autoantibody against pancreatic secretory trypsin inhibitor in patients with autoimmune pancreatitis," Pancreas, vol. 33, no. 1, pp. 20-26, 2006.

[30] T. Endo, S. Takizawa, S. Tanaka et al., "Amylase $\alpha-2$ A autoantibodies novel marker of autoimmune pancreatitis and fulminant type 1 diabetes," Diabetes, vol. 58, no. 3, pp. 732-737, 2009.

[31] Q.-C. Liu, F. Dong, J.-F. Pan et al., "Antibodies to type IV collagen induce type 1 autoimmune pancreatitis," Inflammation, vol. 39, no. 2, pp. 592-600, 2016.

[32] M. S. Castañón, V. Zuliani, A. Amodio et al., "Role of amylase$\alpha 2 \mathrm{~A}$ autoantibodies in the diagnosis of autoimmune pancreatitis," Pancreas, vol. 44, no. 7, pp. 1078-1082, 2015.

[33] T. Watanabe, K. Yamashita, S. Fujikawa et al., "Involvement of activation of toll-like receptors and nucleotidebinding oligomerization domain-like receptors in enhanced IgG4 responses in autoimmune pancreatitis," Arthritis and Rheumatism, vol. 64, no. 3, pp. 914-924, 2012.

[34] T. Watanabe, K. Yamashita, T. Sakurai et al., “Toll-like receptor activation in basophils contributes to the development of IgG4related disease," Journal of Gastroenterology, vol. 48, no. 2, pp. 247-253, 2013.

[35] Y. Fukui, K. Uchida, Y. Sakaguchi et al., "Possible involvement of Toll-like receptor 7 in the development of type 1 autoimmune pancreatitis," Journal of Gastroenterology, vol. 50, no. 4, pp. 435444, 2015.

[36] K. Sumimoto, K. Uchida, T. Kusuda et al., "The role of $\mathrm{CD} 19^{+} \mathrm{CD} 24^{\text {high }} \mathrm{CD} 38^{\text {high }}$ and $\mathrm{CD} 19^{+} \mathrm{CD} 24^{\text {high }} \mathrm{CD} 27^{+}$regulatory B cells in patients with type 1 autoimmune pancreatitis," Pancreatology, vol. 14, no. 3, pp. 193-200, 2014.

[37] H. Miyoshi, K. Uchida, T. Taniguchi et al., "Circulating naïve and $\mathrm{CD} 4^{+} \mathrm{CD} 25$ high regulatory $\mathrm{T}$ cells in patients with autoimmune pancreatitis," Pancreas, vol. 36, no. 2, pp. 133-140, 2008.

[38] T. Kusuda, K. Uchida, H. Miyoshi et al., "Involvement of inducible costimulator- and interleukin 10-positive regulatory $\mathrm{T}$ cells in the development of IgG4-related autoimmune pancreatitis," Pancreas, vol. 40, no. 7, pp. 1120-1130, 2011.

[39] S.-Y. Li, X.-Y. Huang, Y.-T. Chen, Y. Liu, and S. Zhao, "Autoimmune pancreatitis characterized by predominant $\mathrm{CD} 8{ }^{+} \mathrm{T}$ lymphocyte infiltration," World Journal of Gastroenterology, vol. 17, no. 41, pp. 4635-4639, 2011.

[40] K. Okazaki, S. Kawa, T. Kamisawa et al., "Amendment of the Japanese consensus guidelines for autoimmune pancreatitis, 2013 I. Concept and diagnosis of autoimmune pancreatitis," Journal of Gastroenterology, vol. 49, pp. 567-588, 2014.

[41] Y. Song, Q.-D. Liu, N.-X. Zhou, W.-Z. Zhang, and D.-J. Wang, "Diagnosis and management of autoimmune pancreatitis: experience from China," World Journal of Gastroenterology, vol. 14, no. 4, pp. 601-606, 2008.

[42] T. Kamisawa, S. T. Chari, S. A. Giday et al., "Clinical profile of autoimmune pancreatitis and its histological subtypes: an international multicenter survey," Pancreas, vol. 40, no. 6, pp. 809-814, 2011.

[43] Q. Meng, L. Xin, W. Liu et al., "Diagnosis and treatment of autoimmune pancreatitis in China: a systematic review," PLoS ONE, vol. 10, no. 6, Article ID e0130466, 2015. 
[44] A. López-Serrano, J. Crespo, I. Pascual et al., "Diagnosis, treatment and long-term outcomes of autoimmune pancreatitis in Spain based on the International Consensus Diagnostic Criteria: a multi-centre study," Pancreatology, vol. 16, no. 3, pp. 382-390, 2016.

[45] T. Ueki, K. Kawamoto, Y. Otsuka et al., "Prevalence and clinicopathological features of autoimmune pancreatitis in Japanese patients with inflammatory bowel disease," Pancreas, vol. 44, no. 3, pp. 434-440, 2015.

[46] T. Milosavljevic, M. Kostic-Milosavljevic, I. Jovanovic, and M. Krstic, "Extraintestinal manifestations of autoimmune pancreatitis," Digestive Diseases, vol. 30, no. 2, pp. 220-223, 2012.

[47] H. Umehara, K. Okazaki, Y. Masaki et al., "A novel clinical entity, IgG4-related disease (IgG4RD): general concept and details," Modern Rheumatology, vol. 22, no. 1, pp. 1-14, 2012.

[48] M. Dahlgren, A. Khosroshahi, G. P. Nielsen, V. Deshpande, and J. H. Stone, "Riedel's thyroiditis and multifocal fibrosclerosis are part of the IgG4-related systemic disease spectrum," Arthritis Care and Research, vol. 62, no. 9, pp. 1312-1318, 2010.

[49] W. Cheuk, H. K. L. Yuen, S. Y. Y. Chu, E. K. W. Chiu, L. K. Lam, and J. K. C. Chan, "Lymphadenopathy of IgG4-related sclerosing disease," American Journal of Surgical Pathology, vol. 32, no. 5, pp. 671-681, 2008.

[50] J. H. Stone, A. Khosroshahi, V. Deshpande et al., "Recommendations for the nomenclature of IgG4-related disease and its individual organ system manifestations," Arthritis and Rheumatism, vol. 64, no. 10, pp. 3061-3067, 2012.

[51] D. L. Finkelberg, D. Sahani, V. Deshpande, and W. R. Brugge, "Autoimmune pancreatitis," New England Journal of Medicine, vol. 355, no. 25, pp. 2670-2676, 2006.

[52] D. Yadav and A. B. Lowenfels, "The epidemiology of pancreatitis and pancreatic cancer," Gastroenterology, vol. 144, no. 6, pp. 1252-1261, 2013.

[53] G. Maconi, R. Dominici, M. Molteni et al., "Prevalence of pancreatic insufficiency in inflammatory bowel diseases. Assessment by fecal elastase-1," Digestive Diseases and Sciences, vol. 53, no. 1, pp. 262-270, 2008.

[54] Members of the Criteria Committee for Autoimmune Pancreatitis of the Japan Pancreas Society, "Diagnostic criteria for autoimmune pancreatitis by the Japan Pancreas Society," Journal of Japan Pancreas Society, vol. 17, pp. 585-587, 2002 (Japanese).

[55] K. Okazaki, S. Kawa, T. Kamisawa et al., "Clinical diagnostic criteria of autoimmune pancreatitis: revised proposal," Journal of Gastroenterology, vol. 41, no. 7, pp. 626-631, 2006.

[56] S. Kwon, M.-H. Kim, and E. K. Choi, “The diagnostic criteria for autoimmune chronic pancreatitis: it is time to make a consensus," Pancreas, vol. 34, no. 3, pp. 279-286, 2007.

[57] S. T. Chari, T. C. Smyrk, M. J. Levy et al., "Diagnosis of autoimmune pancreatitis: the Mayo clinic experience," Clinical Gastroenterology and Hepatology, vol. 4, no. 8, pp. 1010-1016, 2006.

[58] M. Otsuki, J. B. Chung, K. Okazaki et al., "Asian diagnostic criteria for autoimmune pancreatitis: consensus of the JapanKorea symposium on autoimmune pancreatitis," Journal of Gastroenterology, vol. 43, no. 6, pp. 403-408, 2008.

[59] A. Schneider and J. M. Löhr, "Autoimmune pancreatitis," Internist, vol. 50, no. 3, pp. 318-330, 2009.

[60] The Japan Pancreas Society the Ministry of Health and Welfare Investigation Research Team for Intractable Pancreatic Disease, "Clinical diagnostic criteria for autoimmune pancreatitis 2011 (proposal)," Suizo, vol. 27, no. 1, pp. 17-25, 2012 (Japanese).
[61] T. Shimosegawa, The working Group Members of the Japan Pancreas Society Research Committee for Intractable Pancreatic Disease by the Ministry of Labor, Health, and Welfare of Japan, "The amendment of the clinical diagnostic criteria in Japan (JPS2011) in response to the proposal of the international consensus of diagnostic criteria (ICDC) for autoimmune pancreatitis," Pancreas, vol. 41, no. 8, pp. 1341-1342, 2012.

[62] A. Ghazale, S. T. Chari, T. C. Smyrk et al., "Value of serum IgG4 in the diagnosis of autoimmune pancreatitis and in distinguishing it from pancreatic cancer," American Journal of Gastroenterology, vol. 102, no. 8, pp. 1646-1653, 2007.

[63] T. Tabata, T. Kamisawa, K. Takuma et al., "Serum IgG4 concentrations and IgG4-related sclerosing disease," Clinica Chimica Acta, vol. 408, no. 1-2, pp. 25-28, 2009.

[64] R. Sadler, R. W. Chapman, D. Simpson et al., "The diagnostic significance of serum IgG4 levels in patients with autoimmune pancreatitis: A UK Study," European Journal of Gastroenterology and Hepatology, vol. 23, no. 2, pp. 139-145, 2011.

[65] R. P. Sah and S. T. Chari, "Serologic issues in IgG4-related systemic disease and autoimmune pancreatitis," Current Opinion in Rheumatology, vol. 23, no. 1, pp. 108-113, 2011.

[66] M.-J. Lian, S. Liu, G.-Y. Wu, and S.-Y. Liu, "Serum IgG4 and IgG for the diagnosis of autoimmune pancreatitis: a systematic review with meta-analysis," Clinics and Research in Hepatology and Gastroenterology, vol. 40, no. 1, pp. 99-109, 2016.

[67] T. J. Song, M.-H. Kim, S.-H. Moon et al., "The combined measurement of total serum igg and IgG4 may increase diagnostic sensitivity for autoimmune pancreatitis without sacrificing specificity, compared with IgG4 alone," American Journal of Gastroenterology, vol. 105, no. 7, pp. 1655-1660, 2010.

[68] M. Hao, W. Li, L. Yi et al., "Hybrid kappa\lambda antibody is a new serological marker to diagnose autoimmune pancreatitis and differentiate it from pancreatic cancer," Scientific Reports, vol. 6, Article ID 27415, 2016.

[69] F. Vitali, L. Pfeifer, C. Janson et al., "Quantitative perfusion analysis in pancreatic contrast enhanced ultrasound (DCE-US): a promising tool for the differentiation between autoimmune pancreatitis and pancreatic cancer," Zeitschrift für Gastroenterologie, vol. 53, no. 10, pp. 1175-1181, 2015.

[70] K. D. Bodily, N. Takahashi, J. G. Fletcher et al., "Autoimmune pancreatitis: pancreatic and extrapancreatic imaging findings," American Journal of Roentgenology, vol. 192, no. 2, pp. 431-437, 2009.

[71] D. V. Sahani, S. P. Kalva, J. Farrell et al., "Autoimmune pancreatitis: imaging features," Radiology, vol. 233, no. 2, pp. 345-352, 2004.

[72] N. Takahashi, J. G. Fletcher, J. L. Fidler, D. M. Hough, A. Kawashima, and S. T. Chari, "Dual-phase CT of autoimmune pancreatitis: A Multireader Study," American Journal of Roentgenology, vol. 190, no. 2, pp. 280-286, 2008.

[73] R. Rotzinger, H. Blaker, M. Bahra, T. Denecke, and C. Grieser, "CT and MRI findings of autoimmune polymorph bifocal pancreatitis mimicking pancreatic adenocarcinoma: a case report and review of the literature," Journal of Investigative Medicine High Impact Case Reports, vol. 3, no. 1, 2015.

[74] E. Buscarini, L. Frulloni, S. De Lisi, M. Falconi, P. Testoni, and A. Zambelli, "Autoimmune pancreatitis: a challenging diagnostic puzzle for clinicians," Digestive and Liver Disease, vol. 42, no. 2, pp. 92-98, 2010.

[75] H. Irie, H. Honda, S. Baba et al., "Autoimmune pancreatitis: CT and MR characteristics," American Journal of Roentgenology, vol. 170, no. 5, pp. 1323-1327, 1998. 
[76] N. Kartalis, T. L. Lindholm, P. Aspelin, J. Permert, and N. Albiin, "Diffusion-weighted magnetic resonance imaging of pancreas tumours," European Radiology, vol. 19, no. 8, pp. 1981-1990, 2009.

[77] N. Inan, A. Arslan, G. Akansel, Y. Anik, and A. Demirci, "Diffusion-weighted imaging in the differential diagnosis of cystic lesions of the pancreas," American Journal of Roentgenology, vol. 191, no. 4, pp. 1115-1121, 2008.

[78] Y. Fukukura, K. Takumi, K. Kamimura et al., "Pancreatic adenocarcinoma: variability of diffusion-weighted MR imaging findings," Radiology, vol. 263, pp. 732-740, 2012.

[79] B. Kim, S. S. Lee, Y. S. Sung et al., "Intravoxel incoherent motion diffusion-weighted imaging of the pancreas: characterization of benign and malignant pancreatic pathologies," Journal of Magnetic Resonance Imaging, vol. 45, no. 1, pp. 260-269, 2016.

[80] G. Carbognin, V. Girardi, C. Biasiutti et al., "Autoimmune pancreatitis: imaging findings on contrast-enhanced MR, MRCP and dynamic secretin-enhanced MRCP," Radiologia Medica, vol. 114, no. 8, pp. 1214-1231, 2009.

[81] I. Naitoh, T. Nakazawa, F. Okumura et al., "Endoscopic retrograde cholangiopancreatography-related adverse events in patients with type 1 autoimmune pancreatitis," Pancreatology, vol. 16, no. 1, pp. 78-82, 2016.

[82] T. Nakazawa, H. Ohara, H. Sano et al., "Cholangiography can discriminate sclerosing cholangitis with autoimmune pancreatitis from primary sclerosing cholangitis," Gastrointestinal Endoscopy, vol. 60, no. 6, pp. 937-944, 2004.

[83] S.-H. Moon and M.-H. Kim, "The role of endoscopy in the diagnosis of autoimmune pancreatitis," Gastrointestinal Endoscopy, vol. 76, no. 3, pp. 645-656, 2012.

[84] A. Sugumar, M. J. Levy, T. Kamisawa et al., "Endoscopic retrograde pancreatography criteria to diagnose autoimmune pancreatitis: an international multicentre study," Gut, vol. 60, pp. 666-670, 2011.

[85] A. Kanno, A. Masamune, F. Fujishima et al., "Diagnosis of autoimmune pancreatitis by EUS-guided FNA using a 22gauge needle: A Prospective Multicenter Study," Gastrointestinal Endoscopy, vol. 84, no. 5, pp. 797.el-804.el, 2015.

[86] A. Kanno, K. Ishida, S. Hamada et al., "Diagnosis of autoimmune pancreatitis by EUS-FNA by using a 22-gauge needle based on the International Consensus Diagnostic Criteria," Gastrointestinal Endoscopy, vol. 76, no. 3, pp. 594-602, 2012.

[87] T. Ishikawa, A. Itoh, H. Kawashima et al., "Endoscopic ultrasound-guided fine needle aspiration in the differentiation of type 1 and type 2 autoimmune pancreatitis," World Journal of Gastroenterology, vol. 18, no. 29, pp. 3883-3888, 2012.

[88] M. Ebbo, A. Grados, E. Guedj et al., "Usefulness of 2$\left[{ }^{18} \mathrm{~F}\right]$-fluoro-2-deoxy-d-glucose-positron emission tomography/computed tomography for staging and evaluation of treatment response in IgG4-related disease: A Retrospective Multicenter Study," Arthritis Care and Research, vol. 66, no. 1, pp. 86-96, 2014.

[89] Y. Y. Ozaki, K. Oguchi, H. Hamano et al., "Differentiation of autoimmune pancreatitis from suspected pancreatic cancer by fluorine-18 fluorodeoxyglucose positron emission tomography," Journal of Gastroenterology, vol. 43, no. 2, pp. 144-151, 2008.

[90] K. Uchida, H. Miyoshi, T. Ikeura, M. Shimatani, M. Takaoka, and K. Okazaki, "Clinical and pathophysiological issues associated with type 1 autoimmune pancreatitis," Clinical Journal of Gastroenterology, vol. 9, no. 1, pp. 7-12, 2016.

[91] T. Ngwa, R. Law, P. Hart, T. C. Smyrk, and S. T. Chari, "Serum IgG4 elevation in pancreatic cancer: diagnostic and prognostic significance and association with autoimmune pancreatitis," Pancreas, vol. 44, no. 4, pp. 557-560, 2015.

[92] M. J. van Heerde, J. Buijs, B. E. Hansen et al., "Serum level of ca 19-9 increases ability of IgG4 test to distinguish patients with autoimmune pancreatitis from those with pancreatic carcinoma," Digestive Diseases and Sciences, vol. 59, no. 6, pp. 1322-1329, 2014.

[93] M.-C. Chang, Y.-T. Chang, T.-C. Su et al., "Adiponectin as a potential differential marker to distinguish pancreatic cancer and chronic pancreatitis," Pancreas, vol. 35, no. 1, pp. 16-21, 2007.

[94] T. Kamisawa, K. Okazaki, S. Kawa et al., "Amendment of the Japanese Consensus Guidelines for Autoimmune Pancreatitis, 2013 III. Treatment and prognosis of autoimmune pancreatitis," Journal of Gastroenterology, vol. 49, no. 6, pp. 961-970, 2014.

[95] T. Kamisawa, T. Shimosegawa, K. Okazaki et al., "Standard steroid treatment for autoimmune pancreatitis," Gut, vol. 58, no. 11, pp. 1504-1507, 2009.

[96] A. Ghazale, S. T. Chari, L. Zhang et al., "Immunoglobulin G4associated cholangitis: clinical profile and response to therapy," Gastroenterology, vol. 134, no. 3, pp. 706-715, 2008.

[97] K. Shimizu, J. Tahara, Y. Takayama et al., "Assessment of the rate of decrease in serum IgG4 level of autoimmune pancreatitis patients in response to initial steroid therapy as a predictor of subsequent relapse," Pancreas, vol. 45, no. 9, pp. 1341-1346, 2016.

[98] P. A. Hart, M. D. Topazian, T. E. Witzig et al., "Treatment of relapsing autoimmune pancreatitis with immunomodulators and rituximab: the mayo clinic experience," Gut, vol. 62, no. 11, pp. 1607-1615, 2013.

[99] M. Topazian, T. E. Witzig, T. C. Smyrk et al., "Rituximab therapy for refractory biliary strictures in immunoglobulin G4associated cholangitis," Clinical Gastroenterology and Hepatology, vol. 6, no. 3, pp. 364-366, 2008.

[100] M. Shiokawa, Y. Kodama, K. Yoshimura et al., "Risk of cancer in patients with autoimmune pancreatitis," American Journal of Gastroenterology, vol. 108, no. 4, pp. 610-617, 2013.

[101] P. A. Hart, R. J. Law, R. A. Dierkhising, T. C. Smyrk, N. Takahashi, and S. T. Chari, "Risk of cancer in autoimmune pancreatitis: a case-control study and review of the literature," Pancreas, vol. 43, no. 3, pp. 417-421, 2014. 


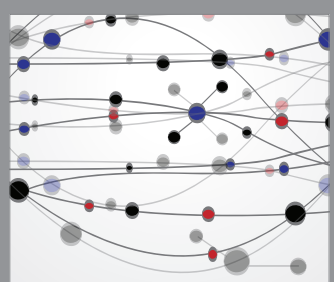

The Scientific World Journal
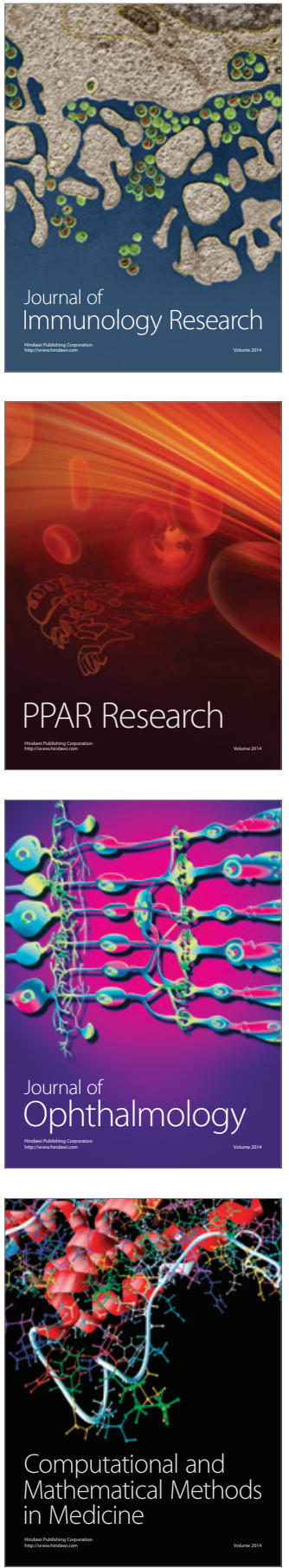

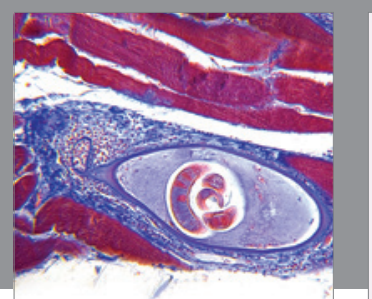

Gastroenterology Research and Practice
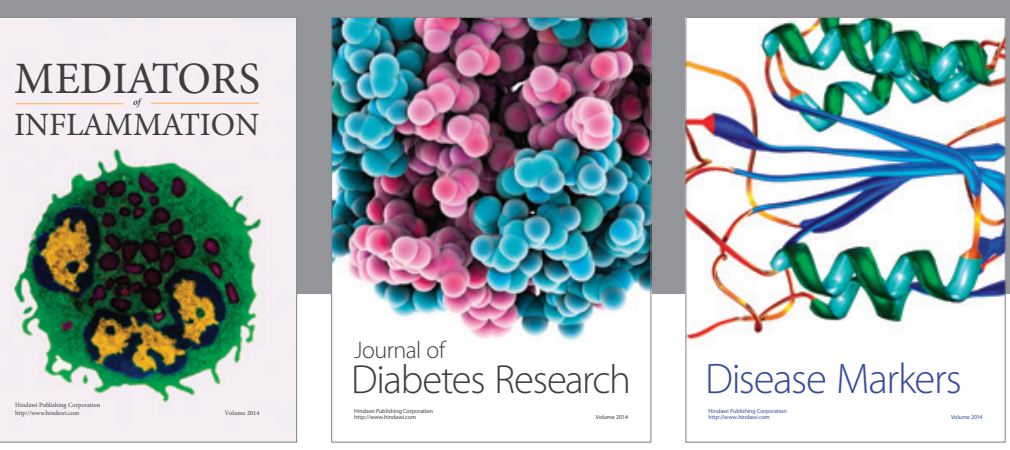

Disease Markers

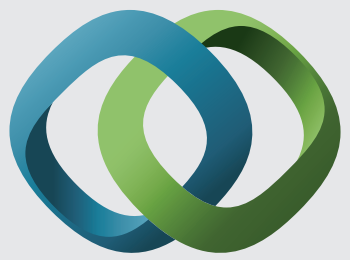

\section{Hindawi}

Submit your manuscripts at

https://www.hindawi.com
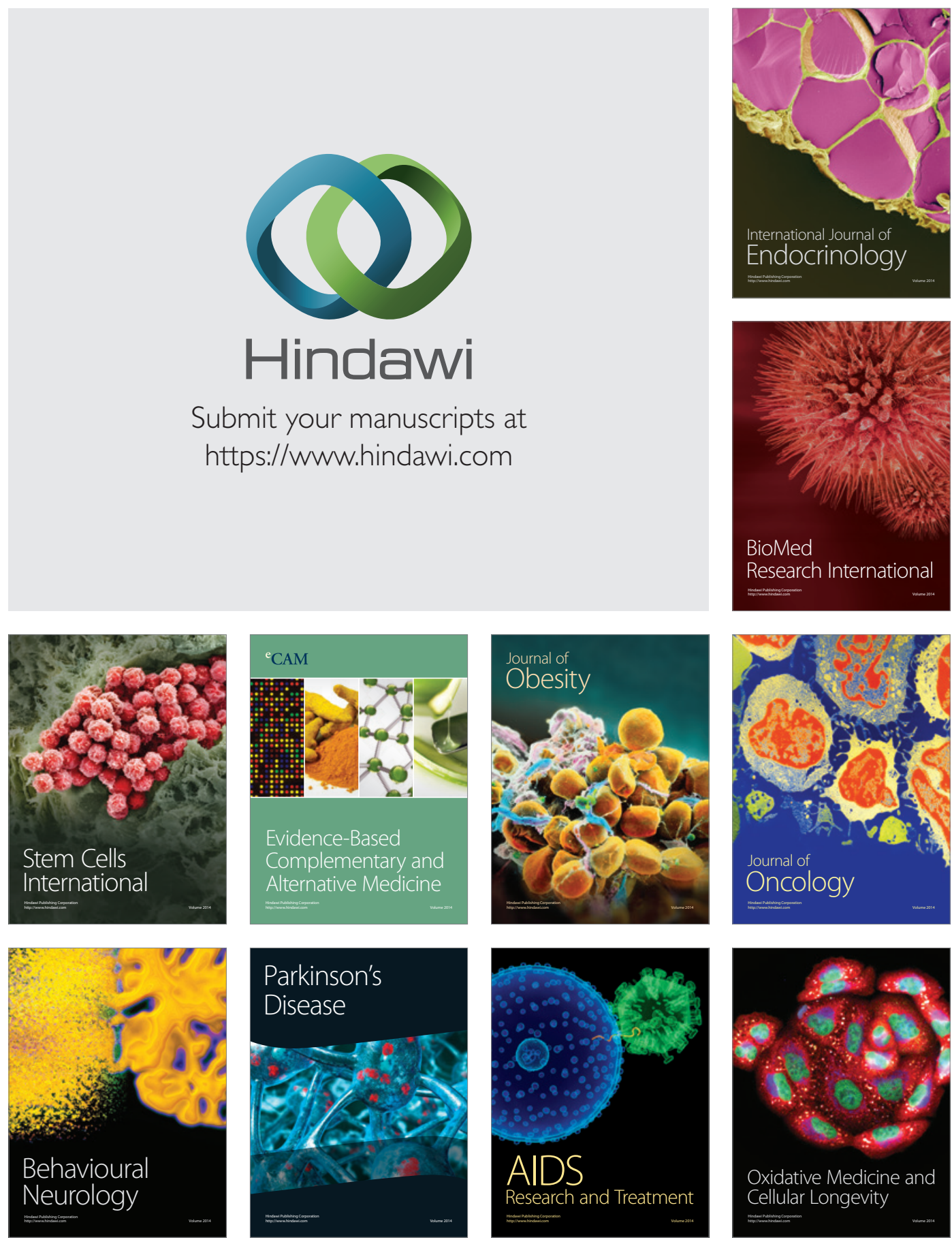